\title{
ANALISIS PENGGUNAAN PARALLEL PROCESSING MULTITHREADING PADA RESILIENT BACKPROPAGATION
}

\author{
Kelvin Onggrono, Tulus, Erna Budhiarti Nababan \\ Magister Teknik Informatika, Universitas Sumatera Utara \\ Jl. Universitas No. 9 A Kampus USU, Medan, Sumatera Utara-Indonesia \\ kelvin_onggrono@yahoo.co.id
}

\begin{abstract}
Abstrak-Proses pembelajaran neural network merupakan hal yang penting, bertujuan untuk mengenali lingkungan. Proses pembelajaran neural network membutuhkan waktu untuk dapat mengenali lingkungan. Terutama pada salah satu algoritma neural network yaitu resilient backpropagation. Proses untuk mempercepat pembelajaran resilient backpropagation pada penelitian ini adalah menggunakan teknik parallel processing. Teknik parallel processing yang digunakan adalah multithreading. Teknik parallel ini diterapkan pada bagian hidden layer yaitu membagi jumlah neuron pada hidden layer menjadi beberapa subproses yang dikerjakan secara bersamaan, pembagian yang dilakukan berdasarkan pada jumlah thread. Hasil yang didapatkan dalam penerapan parallel processing menggunakan teknik multithreading ke dalam algoritma resilient backpropagation membantu mempercepat waktu proses pembelajaran resilient backpropagation dengan thread yang digunakan sebanyak 3 buah thread.
\end{abstract}

Keyword - Neural Network, Resilient Backpropagation, Parallel, Hybrid Partition, Multithreading.

\section{PENDAHULUAN}

Artificial Neural Network (ANN) merupakan komputasi yang mengambil sistem biologi yaitu jaringan saraf, jaringan saraf buatan ini berfungsi untuk melakukan komputasi klasifikasi, pengenalan pola, kontrol, forecasting, dll [1]. Algoritma ANN sebelum diuji pada sebuah lingkungan, ANN perlu melakukantraining terlebih dahulu agar algoritma ANN dapat mengenali lingkungan tersebut. Pada saat algoritma ANN di training maka memakan waktu yang cukup lama tergantung dari besarnya dataset, nilai epoch, kecepatan pembelajaran mencapai titik konvergen [2].

Proses training pada artificial neural network membutuhkan waktu untuk meyelesaikan masalah tersebut salah satu metode yang dapat digunakan adalah adaptive learning rate. Adaptivelearningrate adalah teknik yang digunakan untuk mengubah learningrate berdasarkan pada perubahan nilai errror yang dihasilkan dari setiap iterasi [3]. Selain pengunaan metode adaptive learning rate untuk mempercepat waktu training pada ANN, ada metode lain yang dapat digunakan yaitu memasukan teknik parallel kedalam arsitektur neuralnetwork tersebut. Teknik parallel adalah membagi proses menjadi subproses yang dapat dijalankan secara bersamaan. Penerapan parallel komputer terhadap backpropagation sangat membantu dalam proses training yaitu dapat memangkas waktu training [4].
Resilient Propagation / Resilient Backpropagation (RPROP) adalah salah satu algoritma neuralnetwork yang dilengkapi dengan kemampuan adaptive learning yaitu kemampuan untuk menentukan learning rate yang digunakan berdasarkan nilai error gradien [5]. Algoritma RPROP dalam kasus untuk mengklasifikasikan gigitan ular menunjukan tingkat kecepatan pembelajaran untuk mencapai titik konvergen berdasarkan pada nilai batasan MSE 0.03 dimana standar backpropagation membutuhkan pembelajaran sebanyak 378 epoch sedangkan resilientbackpropagation hanya membutuhkan sebanyak 73 epoch untuk mencapai titik konvergen berdasarkan pada nilai MSE[6]. Algoritma RPROP memiliki kecepatan dalam mencapai nilai konvergen dibandingkan dengan backpropagation. Pada tingkat akurasinya algoritma RPROP berada pada rata $76,88 \%$, sedangkan rata akurasi backpropagation 69,264\% [7]. Kemampuan algoritma RPROP menjadikan pengujian terhadap semua kasus dataset yang diuji sangat stabil dalam pembelajaran [3]. Pada penelitian terdahulu menunjukan kemampuan resilient propagation memiliki keunggulan kecepatan dalam training untuk mencapai titik konvergen dibandingkan dengan backpropagation standar. Pengujian data yang digunakan adalah data kasus klasifikasi aktifitas manusia berdasarkan sensor gyroscope dan accelerometer. 


\section{LANDASAN TEORI}

\section{A. ResilientBackpropagation}

Resilient backpropagation (RPROP) adalah algortima neural network yang bersifat supervised dan adaptive learning. RPROP merupakan perkembangan dari backpropagation. Pada resilient backpropagation parameter sudah ditetapkan jadi tidak diperlukan penentuan learning rate lagi. Kemampuan RPROP adalah untuk menghidari perubahan nilai gradien yang terlalu kecil ini bertujuan agar mempercepat laju pembelajaran RPROP dibandingkan dengan backpropagation, ini ditunjukan pada jaringan RPROP memiliki sebuah nilai delta yang mengikuti perubahan nilai weight. Jika perubahan nilai weight kecil maka nilai delta membesar, sebaliknya ketika perubahan weight aktif maka nilai delta mengecil.

RPROP memiliki langkah yang sama dengan backpropagation yang membedakannya adalah pada waktu backwardnya yaitu pada bagian updateweight. Untuk melakukan updateweight harus dilakukan pemilihan berdasarkan gradien error yang dihasilkan, lalu penentuan learningrate yang dipakai untuk melakukan updateweight.

Pelatihan feedforward pada algoritma resilient propagation sama dengan pelatihan feedforward pada algoritma backpropagation, yang membedakan pada waktu melakukan updateweight dengan learningrate pada pelatihan backward. Perhitungan learningrateakan dijabarkan pada langkah langkah sebagai berikut (Riedmiller \& Braun, 1993):

1) Perhitungan nilai $\Delta_{i}^{(t)}$

Untuk menentukan nilai $\Delta_{i}^{(t)}$ ada beberapa aturan yang harus dipenuhi untuk mendapat nilai delta tersebut yaitu :

$$
\Delta_{i}^{(t)}=\left\{\begin{array}{c}
\eta^{+} * \Delta_{i}^{(t-1)}, i, \frac{\partial E^{(t-1)}}{\partial w_{i}} * \frac{\partial E^{(t)}}{\partial w_{i}}>0 \\
\eta^{-} * \Delta_{i}^{(t-1)}, i, \frac{\partial E^{(t-1)}}{\partial w_{i}} * \frac{\partial E^{(t)}}{\partial w_{i}}<0 \\
\Delta_{i}^{(t-1)}, e
\end{array}\right.
$$

Untuk mendapatkan $\Delta_{i}^{(t)}$ untuk pertama kali pembelajaran $\Delta_{i}^{(t-1)}=\Delta_{0}$. Nilai $\Delta_{0}=0.1$ nilai pada delta 0 dapat saja ditetapkan lebih besar atau lebih kecil dari 0.1, karena nilai delta 0 tidak memiliki pengaruh besar terhadap laju proses pembelajarannya (Martin Riedmiller, 1994). Untuk pembelajaran berikutnya maka $\Delta_{i}$ yang terdahulu akan dikalikan dengan learningrate. Pada perkalian $\Delta_{i}^{(t-1)}$ dengan learningrate ada aturan yang harus dicapai yaitu error gradien pada hasil terdahulu $\frac{\partial E^{(t-1)}}{\partial w_{i}}$ dikalikan dengan errorgradien $\frac{\partial E^{(t)}}{\partial w_{i}}$. Dari hasil perkalian error tersebut maka didapatkan hasil jika hasil lebih besar dari 0 maka $\Delta_{i}^{(t-1)}$ dikalikan dengan $\eta^{+}$, dan jika hasil lebih kecil dari 0 maka $\Delta_{i}^{(t-1)}$ dikalikan dengan $\eta^{-}$. Nilai $\eta^{+}$dan $\eta^{-}$merupakan learningrate yang membedakan adalah pada $\eta^{+}$memiliki nilai yang lebih besar daripada $\eta^{-}$. Marthin Riedmiller (1994) menetapkan nilai standar pada $\eta^{+}=1.2$ sedangkan $\eta^{-}=0.5$ untuk algoritma resilient propagation.

2) Penentuan nilai $\Delta w_{i}^{(t)}$

Setelah ditentukan $\Delta_{i}^{(t)}$ maka akan dilanjutkan ke dalam aturan untuk menentukan fungsi operator yang akan dipakai untuk melakukan updateweight dengan aturan sebagai berikut:

$$
\begin{aligned}
& \Delta w_{i}^{(t)}=\left\{\begin{array}{c}
-\Delta_{i}^{(t)}, i \frac{\partial E^{(t)}}{\partial w_{i j}}>0 \\
+\Delta_{i}^{(t)}, i \frac{\partial E^{(t)}}{\partial w_{i}}<0 \\
0, e
\end{array}\right. \\
& w_{i}^{(t+1)}=w_{i}^{(t)}+\Delta w_{i}^{(t)}
\end{aligned}
$$

Dengan menggunakan error function maka diketahui $\Delta_{i}^{(t)}$ yang akan digunakan apakah akan dikurangi atau ditambah atau tidak terjadi perubahan bobot. Untuk menentukan fungsi operator yang dipakai pada $\Delta_{i}^{(t)}$ maka dibandingkan nilai error gradien terhadap nol. Jika nilai error gradien lebih besar daripada nol maka $\Delta w_{i}^{(t)}$ akan menerimanilai $-\Delta_{i}^{(t)}$, dan jika nilai error gradien lebih kecil daripada 0 maka $\Delta w_{i}^{(t)}$ akan menerima $+\Delta_{i}^{(t)}$. Setelah mendapatkan nilai delta $\mathrm{w}$ maka dilanjutkan ke updateweightnya secara langsung.

Pada aturan pertama untuk penentuan learningrate memiliki masalah pada aturan kedua yaitu terjadi peningkatan pembelajaran yang melebih batas minimum maka dilakukan pengurangan weight secara langsung dengan weight terdahulunya.

$$
\Delta w_{i}^{(t)}=-\Delta w_{i}^{(t-1)}, \text { if } \frac{\partial E^{(t-1)}}{\partial w_{i}} * \frac{\partial E^{(t)}}{\partial w_{i}}<0
$$


Untuk menghindari terjadi keadaan tersebut untuk terjadi kedua kalinya maka pada $\frac{\partial E^{(t)}}{\partial w_{i}}=0$.

\section{B. ParallelProcessing}

Parallel processing adalah sebuah kegiatan menjalankan beberapa proses sekaligus dalam waktu yang bersamaan. Teknik parallel processing ada 2 macam yaitu SIMD (Single Instruction Multiple Data streams) dan MIMD (Multiple Instruction Multiple Data streams).

SIMD (Single Instruction Multiple Data streams) adalah teknik parallel yang menggunakan sebuah control unit dan processor melakukan eksekusi terhadap instruksi yang sama ini ditunjukan pada Gbr 1

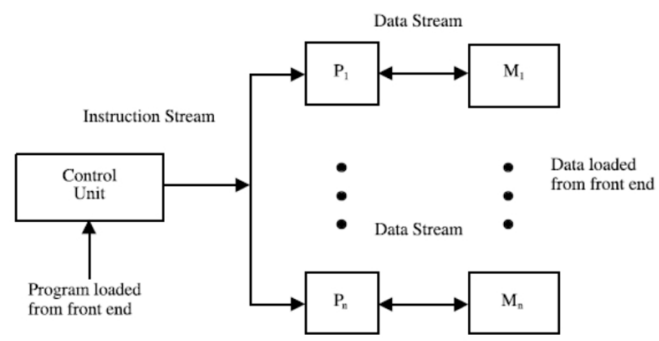

Gbr. 1 Single Instruction Multiple Data streams (Sumber :El-Rewini \& AbdEl-Barr, 2005)

MIMD (Multiple Instruction Multiple Data streams) adalah teknik parallel yang menggunakan multiple processor dan multiple memory yang tergabung dalam sebuah koneksi. Pada MIMD setiap processor memiliki control unit sendiri yang dapat memberikan instruksi yang berbeda. Arsitektur dari MIMD akan ditunjukan pada Gbr 2.

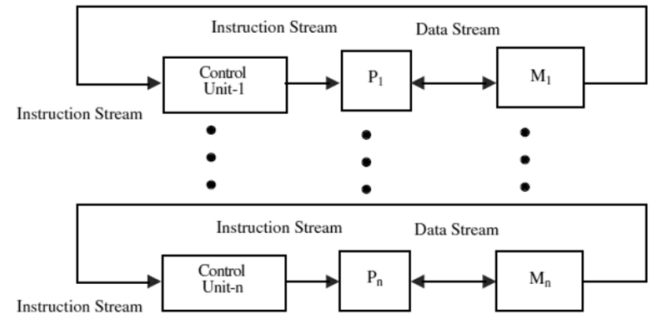

Gbr. 2 Multiple Instruction Multiple Data streams (Sumber : El-Rewini \& Abd-El-Barr, 2005)

Implementasi parallel processing maka digunakan multithreading untuk mengimplementasikan parallel processing tersebut.

\section{Thread \& Multithreading}

Thread adalah sebuah proses yang berukuran kecil yang dibuat oleh sebuah program untuk dijalankan bersamaan dengan thread - thread lainnya. Tujuan thread ini adalah agar proses - proses yang dapat dikerjakan bersamaan dapat dijalankan secara bersamaan tanpa memerlukan waktu tunggu untuk proses berikutnya. Ini dapat dicontohkan dari perangkat lunak pengolah kata yang membentuk beberapa thread untuk melakukan fungsi tampilan, proses pengetikan, dan proses pemeriksaan jumlah kata, dengan pembagian fungsi tersebut kedalam thread maka semua proses tersebut dapat dijalankan secara bersamaan tanpa terjadinya delay, sehingga dapat disebut berjalan secara parallel.

Multithreading adalah kumpulan beberapa thread yang dijalankan bersamaan pada sebuah processor. Pada multithreading ini merupakan proses eksekusi dari kumpulan thread dimana kumpulan thread tersebut diproses secara berulang - ulang dengan perpindahan dalam waktu nanosecond.

D. Parallel Arsitektur Neural Network

Parallel arsitektur neural network mengikuti penelitian dari Ganeshamoorthy \& Ranasinghe, 2008. Parallel yang digunakan adalah Hybrid partition pada metode parallel ini tidak membutuhkan siklus pembelajaran per pola hanya melakukan penyimpanan nilai - nilai weight pada masing - masing neuron hidden unit. Bentuk arsitektur dari parallel neural network tersebut ditunjukan pada Gbr. 3

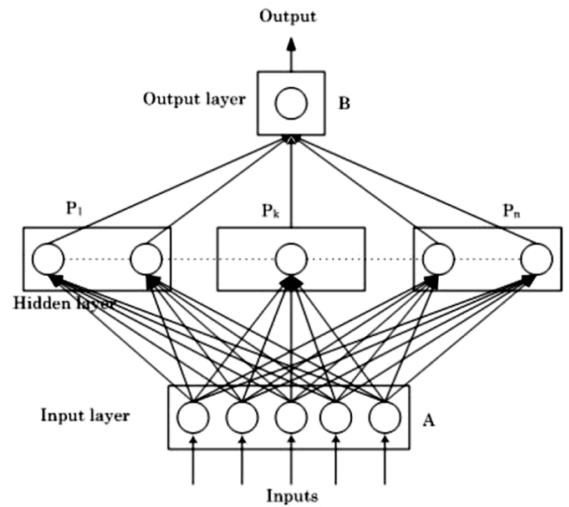

Gbr. 3 Arsitektur NeuralNetwork dengan parallel (Ganeshamoorthy \& Ranasinghe, 2008)

Gbr 3 adalah sebuah teknik parallel yang bernama hybrid partition yaitu membagi arsitektur proses pada neuralnetwork menjadi subproses - subproses. Subproses tersebut dikerjakan pada waktu yang bersamaan dengan menggunakan teknik multithreading. Proses yang akan dilakukan adalah dari inputlayer (A) akan mengirimkan data input yang telah dikalikan dengan weight ke neuron $(\mathrm{P} 1)$ dan nilai tersebut akan dihasilkan nilai function yang akan diteruskan ke output 
(B). Proses di hiddenlayer yaitu P1, Pk, dan Pn dijalankan bersamaan dengan memproses nilai dari A dan diteruskan ke B.

\section{METODE PENELITIAN}

A. Tahapan - Tahapan Penelitian

Tahapan - tahapan penelitian bertujuan penelitian yang dilaksanakan tidak keluar dari jalur yang ditentukan. Tahapan penelitian yang dilakukan dijabarkan pada Gbr. 3.1.

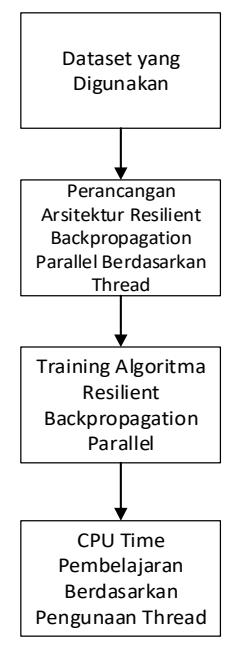

Gbr. 4 Diagram Tahapan - Tahapan Penelitian

B. Data yang Digunakan

Dataset adalah kumpulan data yang digunakan untuk pembelajaran dan ujicoba pada artificialneural network. Dataset yang digunakan berasal dari UCI Machine Learning dengan data HAR (Human Activity Recognition). Dataset HAR ini berisi data - data sensor dari accelerometer dan gyroscope menggunakan smartphone jenis Samsung Galaxy S II yang diletakan pada pinggang. Penelitian yang dilakukan menggunakan data dari sensor accelerometer dan gyroscope. Dataset HAR terdiri dari dua jenis data sensor dan data yang diambil adalah sensor accelerometer dan gyroscope, pada dataset ini telah disedikan dataset untuk training dan testing.

Dataset sensor accelerometer dan gyroscope didapatkan tiga buah nilai axial yaitu nilai x, y, dan z. Jumlah kasus pada masing - masing nilai axial tersebut adalah 7352 kasus. Kasus tersebut adalah aktifitas yang dilakukan oleh volunteers berjumlah 30 volunteers. Aktifitas yang dilakukan oleh volunteers yaitu berjalan, menaiki tangga, menuruni tangga, duduk, berdiri, dan tidur. Dari setiap aktifitas yang dilakukan tersebut menghasilkan nilai axial - nya yaitu $\mathrm{x}, \mathrm{y}$, dan $\mathrm{z}$. Nilai triaxial tersebut diekstrak menjadi 561 feature data.
C. Rancangan Arsitektur Resilient BackpropagationParallel Rancangan arsitektur resilient backpropagation parallel dibagin menjadi tiga bagian utama yaitu input layer, hidden layer, dan output layer. Pada masing - masing layer ada memiliki node, pada input layer node yang dimiliki sebanyak 561 input, hidden layer memiliki node sebanyak 378 node, dan ouput layer memiliki 6 node. Gambar arsitektur resilient backpropagation adalah sebagai berikut

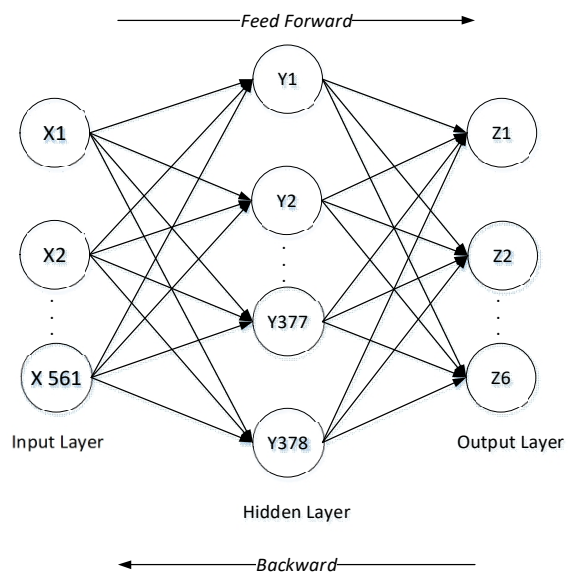

Gbr. 5 Arsitektur Neural Network Resileint Backpropagation

Arsitektur nerural network pada bagian hidden layer node dibagi menjadi beberapa bagian yang akan diproses secara bersamaan menggunakan teknik parallel multithreading. Pada pembagian node pada hidden layer untuk penelitian ini dijelaskan pada tabel berikut ini :

TABEL I

PEMBAGIAN NEURON HIDDEN LAYER BERDASARKAN JUMLAH THREAD

\begin{tabular}{|c|c|c|}
\hline $\begin{array}{c}\text { Thread yang } \\
\text { terbentuk }\end{array}$ & $\begin{array}{c}\text { Hidden Neuron pada } \\
\text { sebuah Thread }\end{array}$ & $\begin{array}{c}\text { Total Neuron pada } \\
\text { HiddenLayer }\end{array}$ \\
\hline 1 & 378 & 378 \\
\hline 2 & 189 & 378 \\
\hline 3 & 126 & 378 \\
\hline 4 & 94 & 378 \\
\hline 5 & 75 & 378 \\
\hline 6 & 63 & 378 \\
\hline 7 & 54 & 378 \\
\hline
\end{tabular}

D. CPU Time untuk ParallelProcessing

Analisis CPU Time jaringan arsitektur neuralnetworkparallelprocessing ini difokuskan pada setiap iterasi yang diproses oleh jaringn neuralnetwork. Hasil CPU Time yang dihasilkan adalah waktu per iterasi, dan total CPU Time pemebelajaran aka didapatkan dari total dari seluruh iterasi. 


$$
T=\sum_{i=1}^{n} I_{i}
$$

T adalah total waktu jaringan neuralnetwork. $l_{i}$ adalah waktu iterasi. Waktu yang dihasilkan sebanyak 7 total waktu dari masing - masing thread yang diuji. Pengujian yang dilakukan adalah sebanyak 3 kali ini dilakukan karena hasil CPU Time yang dihasilkan tidaklah sama pada setiap waktu karena tergantung pada proses komputer tersebut, sehinga harus dilakukan tiga kali pengujian untuk memastikan jumlah thread yang cepat melakukan pembelajaran neuralnetwork. Pengujian yang dilakukan sebanyak tiga kali maka harus dicari rata rata nilai tersebut dengan menggunakan rumus sebagai berikut:

$$
R=\frac{\sum_{i=1}^{3} T_{i}}{3}
$$

RT adalah merupakan rata - rata waktu, dan $\sum_{i=1}^{3} T_{i}$ merupakan jumlah total dari 3 pengujian tersebut dan dibagi dengan banyak pengujian tersebut dilakukan yaitu 3 .

\section{A. Hasil}

\section{HASIL DAN PEMBAHASAN}

Pengujian dilakukan sebanyak tujuh kali pengujian berdasarkan jumlah thread yang telah ditentukan pada metode penelitian. Pengujian yang dilakukan ini berdasarkan banyak thread yang digunakan pada arsitektur neuralnetwork. Pengujian yang diberikan dilakukan sebanyak tiga kali testing untuk mendapatkan waktu rata - rata pada ketujuh pengujian tersebut.

Hasil waktu dari algoritma resilientbackpropagation dengan menggunakan teknik parallelprocessing menggunakan threading ditampilkan dalam bentuk tabel, hasil pengujian dilakukan sebanyak tiga kali sehingga ditampilkan tiga bentuk tabel pengujian dengan bentuk pengujian yang sama yaitu pada setiap tabel akan menampilkan tujuh bagian yang diselesaikan oleh masing - masing thread bertujuan untuk mengetahui waktu yang diselesaikan pada masing - masing thread dan dibandingkan thread manakah yang memiliki waktu proses yang paling cepat selesai.

Pengujian pada pertama kali resilientbackpropagation disajikan dalam Tabel 2 sebagai lanjutannya.
TABEL II

HASIL PENGUJIAN I RESILIENT BACKPROPAGATION PARALLEL MULTITHREADING

\begin{tabular}{|c|c|c|}
\hline Thread & Waktu Selesai/detik & $\begin{array}{c}\text { Rata }- \text { Rata Waktu } \\
\text { Iterasi/detik }\end{array}$ \\
\hline 1 & 27293.694772998733 & 1.3646847386499366 \\
\hline 2 & 25413.755037002018 & 1.270687751850101 \\
\hline 3 & 23914.01629200012 & 1.195700814600006 \\
\hline 4 & 25231.32637700154 & 1.261566318850077 \\
\hline 5 & 25519.277693998476 & 1.2759638846999237 \\
\hline 6 & 26835.739719997993 & 1.3417869859998997 \\
\hline 7 & 27292.983101998594 & 1.3646491550999298 \\
\hline
\end{tabular}

Tabel 2 menunjukan pada pengujian pertama kali mendapatkan hasil yaitu menggunakan 3 buah thread pada arsitektur neuralnetworkresilientbackpropagation pada dapat diselesaikan dalam waktu 23914,01629200012 / detik atau 6,643782 jam. Sedangkan pada pada proses yang menggunakan satu buah thread dan tujuhbuah thread menunjukan hasil yang hampir sama yaitu 27293,694772998733 / detik untuk satu buah thread dan 27292,983101998594 / detik untuk tujuh buah thread, hanya menunjukan perbedaan 1 detik saja. Pada tbl 2 pada pengujian pertama ini menunjukan terjadi kecepatan penyelesaian yang dimulai dari penggunaan satu buah thread sampai tiga buah thread tapi setelah empat buah thread menunjukan perlambatan waktu penyelesaian dan ini terjadi pada terus pada lima buah thread sampai tujuh buah thread. Untuk hasil grafik dari peningkatan kecepatan pada penggunaan thread ditunjukan pada Gbr. 6

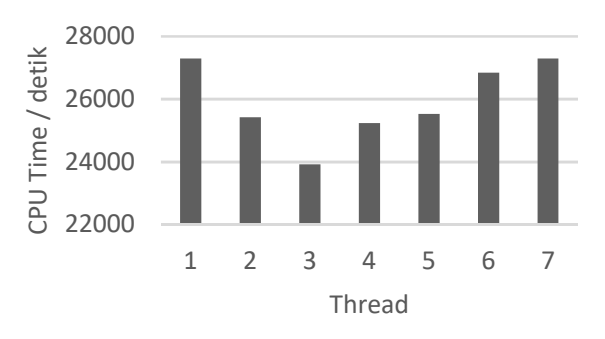

Gbr. 6 Grafik Peningkatan Kecepatan Waktu Berdasarkan Peningkatan Jumlah Thread Pengujian I

Pada pengujian yang kedua menunjukan hasil sama pada pengujian pertama yaitu 3 buah thread cepat dalam penyelsaian tapi berbeda waktu penyelesaiannya pada pengujian yang pertama yaitu pada pengujian yang pertama menunjukan CPU time yang diselesaikan 23914,01629200012 / detik pada pengujian yang kedua waktu selesai23910,218218001297 / 
detik, lebih cepat 4 detik dalam penyelesaian waktunya. Hasil dari pengujian yang kedua ini ditampilkan dalam Tbl 3 dan untuk grafik ditampilkan pada Gbr. 7

TABEL III

HASIL PENGUJIAN II RESILIENT BACKPROPAGATION PARALLEL MULTITHREADING

\begin{tabular}{|c|c|c|}
\hline \multirow{2}{*}{ Thread } & Waktu Selesai / detik & $\begin{array}{c}\text { Rata - Rata Waktu } \\
\text { Iterasi/detik }\end{array}$ \\
\hline 1 & 27290.439604999618 & 1.3645219802499808 \\
\hline 2 & 25172.112700000416 & 1.2586056350000208 \\
\hline 3 & 23910.218218001297 & 1.1955109109000648 \\
\hline 4 & 24732.658940000627 & 1.2366329470000312 \\
\hline 5 & 25274.041188002 & 1.2637020594001 \\
\hline 6 & 26885.634780998025 & 1.3442817390499013 \\
\hline 7 & 27160.287975998206 & 1.3580143987999103 \\
\hline
\end{tabular}

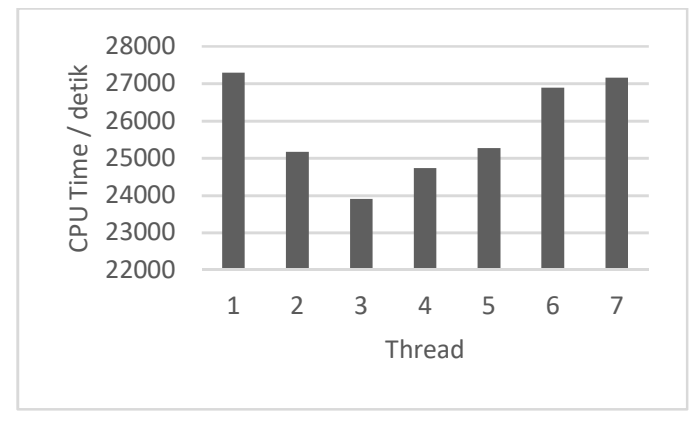

Gbr. 7 Grafik Peningkatan Kecepatan Waktu Berdasarkan Peningkatan Jumlah Thread Pengujian II

Pada pengujian yang ketiga menampilkan hasil sama yaitu dengan menggunakan 3 buah threadmenunjukan kecepatan waktu penyelesaian yang lebih cepat daripada thread lainnya, tetapi waktu penyelesaian berbeda yaitu pengujian ketiga waktu diselesaikn dalam 24067.489326000406 / detik, pengujian kedua waktu selesai 23910.218218001297 / detik, dan pengujian pertama waktu selesai23914.01629200012 / detik. Hasil pengujian iniakan ditampilkan pada Tbl 4 dan untuk grafik waktu akan ditampilkan pada Gbr. 8.

TABEL IV

HASIL PENGUJIAN III RESILIENT BACKPROPAGATION PARALLEL MULTITHREADING

\begin{tabular}{|c|c|c|}
\hline Thread & Waktu Selesai/detik & $\begin{array}{c}\text { Rata }- \text { Rata Waktu } \\
\text { Iterasi/detik }\end{array}$ \\
\hline 1 & 32389.488616999854 & 1.6194744308499927 \\
\hline 2 & 27906.764599999868 & 1.3953382299999935 \\
\hline 3 & 24067.489326000406 & 1.2033744663000203 \\
\hline 4 & 25553.457462000133 & 1.2776728731000067 \\
\hline
\end{tabular}

\begin{tabular}{|c|c|c|}
\hline 5 & 25500.42951299844 & 1.2750214756499219 \\
\hline 6 & 26590.765166998073 & 1.3295382583499036 \\
\hline 7 & 27500.32026299811 & 1.3750160131499054 \\
\hline
\end{tabular}

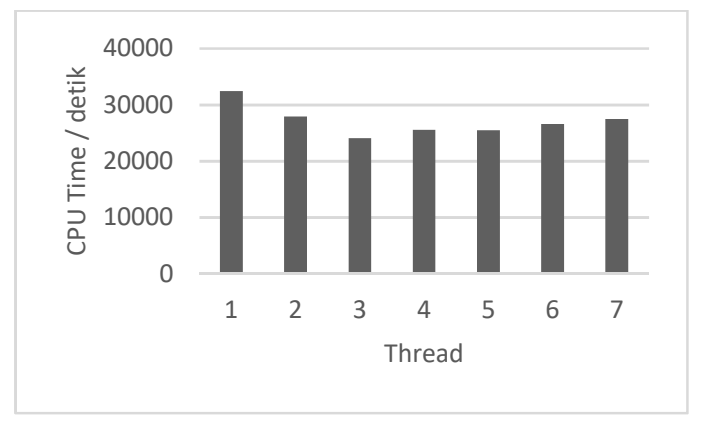

Gbr. 8 Grafik Peningkatan Kecepatan Waktu Berdasarkan Peningkatan Jumlah Thread Pengujian II

Hasil pengujian pada Tbl 2, Tbl 3, dan Tbl 4 menunjukan hasil waktu yang bervariasi. Karena hasil yang bervariasi maka ketiga pengujian tersebut di-average waktunya selesai dari hasil pengujian tersebut.

$$
R \quad-R \quad W \quad=\frac{\sum_{i=1}^{n} w_{i}}{n}
$$

Hasil rata - rata pengujian tersebut ditunjukan pada Tabel 5 sebagai berikut

TABEL V

HASIL PENGUJIAN RATA - RATA RESILIENT BACKPROPAGATION PARALLEL MULTITHREADING

\begin{tabular}{|c|c|c|}
\hline Thread & $\begin{array}{c}\text { Waktu Selesai / } \\
\text { detik }\end{array}$ & $\begin{array}{c}\text { Rata - Rata Waktu Iterasi / } \\
\text { detik }\end{array}$ \\
\hline 1 & 28991,20766 & 1,449560383 \\
\hline 2 & 26164,21078 & 1,308210539 \\
\hline 3 & 23963,90795 & 1,198195397 \\
\hline 4 & 25172,48093 & 1,258624046 \\
\hline 5 & 25431,24946 & 1,271562473 \\
\hline 6 & 26770,71322 & 1,338535661 \\
\hline 7 & 27317,86378 & 1,365893189 \\
\hline
\end{tabular}

Pada pengujian pertama sampai pengujian ketiga bahwa dengan menggunakan 3 thread pada arsitektur neuralnetwork menunjukan waktu proses pembelajaran pada jaringan tersebut lebih dibandingkan dengan enam pengujian thread lainnya. Pada pengabungan waktu berfungsi untuk melihat hasil rata - rata waktu penyelesaian masing - masing thread pada tiga pengujian tersebut. Hasil tampilan grafik waktu rata - rata waktu tersebut ditampilkan pada Gambar 4.4. 


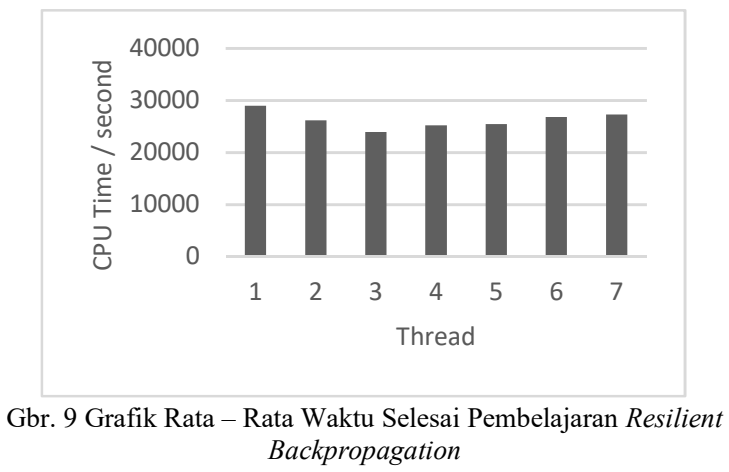

Hasil penelitian yang telah dilakukan pada bagian diatas menunjukan 3 buahthread membantu dalam mempercepat waktu training, dengan jumlah neuroan pada hiddenlayer sebanyak 378 neuron.

\section{B. Pembahasan}

Hasil pengujian yang telah dilakukan mendapatkan bahwa jaringan neuralnetwork yaitu resilientbackpropagation dengan menambahkan teknik parallelprocessing yang diimplementasikan menggunakan multithreading menunjukan membantu kinerja pembelajaran dari jaringan neuralnetworkresilientbackpropagation. Ini ditunjukan dari hasil rata - rata waktu pengujian kecepatan pembelajaran yaitu dibuktikan dari thread satu sampai thread tiga didapatkan penurunan waktu ini menunjukan kecepatan pembelajaran thread tiga lebih cepat dari pada thread satu dan thread dua. Tetapi thread empat menunjukan waktu yang berangsur angsur naik sampai thread ke tujuh, ini menunjukan waktu pembelajaran menjadi lebih lambat.

Penurunan kecepatan yang dimulai dari penggunaan empat buah thread ini dapat disebabkan oleh kemampuan hardware yang digunakan dan pergantian antar thread yang terjadi. Pengunaan hardware yaitu Core i3 dengan dua core pada masing - masing core dapat menjalankan duathread sekaligus, karena kemampuan ini dapat memproses empatthread pada waktu yang bersamaan. Proses pada jaringan neuralnetwork menggunakan parallelprocessing dengan teknik multithreading, pada satuthread maka yang terjadi ada adanya penggunaan duathread yaitu satuthread untuk memproses semua neuron pada hidden layer dan satuthread sebagai melakukan pengecekan terhadap proses neuron pada hidden layer apakah sudah selesai semua. Pada saat duathread maka yang terjadi adalah pembentukan sebanyak duathread untuk memproses neuron pada hidden layer dan satuthread sebagai pengecekannya. Pada saat tigathread maka yang berjalan adalah empatthread yaitu tigathread memproses neuron pada hidden layer dan satuthread sebagai pengecekan. Pada setiap thread yang digunakan maka ditambah satu thread sebagai pengecekan proses pada hidden layer. Oleh sebab itu pemanfaatan thread yang paling optimal adalah tigathread karena penggunaan seluruh kemampuan hardware. Tetapi pada saat penggunaan empatthread maka yang terjadi adalah pengantian proses antar thread yaitu thread diproses secara bergantian pada hardware secara berulang - ulang sampai proses tersebut selesai. Oleh sebab itu terjadi kenaikan waktu proses karena perpindahaan antar thread tersebut.

\section{KESIMPULAN DAN SARAN}

A. Kesimpulan

Kesimpulan dari hasil penelitian yang dilakukan yaitu:

1. Parallel processing menggunakan multithreading yang diterapakan ke dalam arsitektur resilient backpropagation membantu kinerja waktu pembelajaran resilient backpropagation dengan hanya memanfaatkan 3 thread pada kasus pengenalan aktifitas manusia.

2. Pengunaan lebih dari 3 thread pada arsitektur resilient backpropagation menyebabkan penurunan waktu pembelajaran yaitu lebih lambat, ini disebabkan oleh terjadi proses perpindahaan antar thread sehingga terjadi penambahaan waktu pada setiap perpindahaan thread tersebut.

B. Saran

Saran yang diberikan oleh penulis adalah sebagai berikut:

1. Penggunaan parallel dengan multithreading terhadap arsitektur resilient backpropagation harus memperhatikan jumlah thread yang dapat diproses pada waktu bersamaan pada sebuah CPU karena ini berpengaruh terhadap eksekusi thread yang dapat menyebabkan waktu delay pada perpindahaan antar thread tersebut.

2. Untuk meningkatkan kemampuan parallel processing pada arsitektur resilient backpropagation dapat menggunakan multiprocessor yaitu menggunakan beberapa processor pada waktu bersamaan.

\section{REFERENCES}

[1] K. Ganeshamoorthy and D. N. Ranasinghe, "On the Performance of Parallel Neural Network Implementations on Distributed Memory Architectures," in Cluster Computing and the Grid, 2008. CCGRID '08. 8th IEEE International Symposium on, Lyon, 2008.

[2] R. Gu, F. Shen and Y. Huang, "A Parallel Computing Platform for Training Large Scale Neural Networks," in Big Data, 2013 IEEE International Conference on, Silicon Valley, CA, 2013.

[3] M. Moreira and E. Fiesler, "Neural Nerworks with Adaptive Learning Rate and Momentum Terms," IDIAP Technical Report, 1995.

[4] J. Torresen, Parallelization of Backpropagation Training fo Feed Forward Neural Networks, Norwegian: The University of Trondheim, 1996. 
[5] M. Riedmiller and H. Braun, "A Direct Adaptive Method for Faster Backpropagation Learning : The RPROP Algorithm," in IEEE International Conference, San Francisco, CA, 1993.

[6] S. A. Halim, A. Ahmad, N. M. Noh, M. S. B. M. A. Safudin and R. Ahmad, "A Comparative Study between Standard Back Propagation and Resilient Propagation," in IT in Medicine and Education (ITME), 2011 International Symposium on, Cuangzhou, 2011.

[7] N. Prasad, R. Singh and S. P. Lal, "Comparison of Back Propagation and Resilient Propagation Algorithm for Spam Classification," in 2013 Fifth International Conference on Computational Intelligence, Modelling and Simulation, Seoul, 2013.

[8] J. Stubbemann, O. Kramer and N. A. Treiber, "Resilient Propagation for Multivariate Wind Power Prediction," 2015. [Online]. Available: http://www.researchgate.net/profile/Oliver_Kramer2/publication/268966 338 Resilient Propagation for Multivariate Wind Power Prediction/1 inks/55360e290cf20ea35f10f924.pdf. 